\title{
Weed Management in Rice-Garlic under Organic Production System
}

\author{
A. Singraul, B. M. Maurya, S. M. Kurmvanshi and Y. K. Pradhan* \\ All India Coordinated Research Project on Integrated Farming System, Kuthulia farm, \\ JNKVV College of Agriculture, Rewa(M.P.), India. \\ *Corresponding author
}

\section{A B S T R A C T}

\begin{tabular}{l} 
Key w or d s \\
Rice, Garlic, \\
Organic production \\
system, Weed \\
management and \\
Organic farming \\
\hline Article Info \\
\hline $\begin{array}{l}\text { Accepted: } \\
12 \text { October } 2020 \\
\text { Available Online: } \\
10 \text { November } 2020\end{array}$ \\
\hline
\end{tabular}

A field experiment on weed management in rice-garlic under organic production system was conducted during 2017-18 to 2019-20 at All India Coordinated Research Project on Integrated Farming System, Rewa (M.P.). The study reveals that maximum grain yield of rice and bulb yield of garlic was noted under incorporation of mustard oilcake @ 50 quintal per hectare with one hand weeding followed by two hand weeding at different stages under organic production system. The net profit Rs/- 2,36,900/ha was maximum under two hand weeding given in rice and garlic followed by Rs/- 1,72,516/ha under incorporation of mustard oilcake @ 50 quintal per hectare with one hand weeding as weed control treatment in both the crops. Benefit cost ratio 2.24 was maximum under two hand weeding treatment followed by 2.08 under one hoeing + one hand weeding given in rice and garlic as weed control practices under organic production system.

\section{Introduction}

Rice is the important crop of rice-wheat crop zone of Madhya Pradesh which occupies an area of 1.93 million hectares with the average production of 2.78 million tonnes (Anonymous 2017). The average productivity of rice is $1.44 \mathrm{t} / \mathrm{ha}$, which is low due to use of local varieties, erratic and uneven distribution of monsoon rain as well as frequently observed prolonged dry spells. In recent years, garlic crop is also becoming an important crop after rice in rabi which occupies 450 hectares of land in Rewa district. Organic farming is the production system that avoids the use of synthetic / chemical fertilizer, pesticides, growth regulating hormones and raises the crop with the use of organic manures, biofertlizers, oilcakes, crop rotation with legumes, green manures and biological pest and weed control.

But feasibility of organic farming in commercial crop production is not good due to low production \& productivity. Beside these weeds are most limiting factor in organic farming. None of the cultural practices has been found effective to reduce the weed problem in rice and garlic under organic production system and thus grain 
yield of rice reduced upto 57 to $61 \%$ (Mukherjee et al 2008). Some cultural practices like intercropping of dhaincha in rice, close row spacing or high seed rate, stale seed bed, mulching with crop residues or tree leaves, hand weeding and hoeing are being found effective to reduce the weed problem under organic production system. On the other hand, practices that aimed at enhancing competitive availability of the crop can bring down the adverse effect of weed on rice and garlic crop. Seedling vigour, early growth rate, profuse tillering ability, stale seed bed, higher fertilizers dose, hoeing and mulching are the practices that provide competitive advantage to the crop.

Use of mustard oil cake at higher level has been found beneficial as it increases the growth character of rice which has ability to suppress the weed growth (Islam et al 2007). Intercropping suppress weeds better than sole cropping and thus provides an opportunity to utilize crop themselves as tools for weed management (Rao and Shetty 1976). Cultivation of rice and garlic at narrow or close row spacing has been found effective to reduce the weed growth and increase the yield as compared to wider spaced crop (Bhan 1968).

It has been reported by Bond and Grundy (2001) that organic farming is gaining momentum in India owing to the concern expressed on the safety of environment, soil, water and food chain. Cultivating high value crops organically and at the same time maintaining higher production level is a big challenge specially weed management with non chemical method in field crops like paddy and garlic under organic farming.

\section{Materials and Methods}

The present field investigation was taken on silty clay loam soil of All India Coordinated Research Project on Integrated Farming
System, Kuthuliya Farm of JNKVV College of Agriculture, Rewa, Madhya Pradesh during kharif and Rabi season of 2017-18 to 201920. Experimental field was neutral in reaction $\mathrm{pH}(7.1)$, low in organic carbon $(4.2 \mathrm{gm} / \mathrm{kg})$, low in available nitrogen (180.3 kg/ha) and phosphorus (16.9 kg/ha). Experimental field was higher in available potash $(283.6 \mathrm{~kg} / \mathrm{ha})$.

The rice variety was Pusa Sugandha 5 while garlic variety was G-1. The row to row spacing was kept $20 \mathrm{~cm}$ in rice and garlic in all the treatments except T4 where row to row spacing was kept $15 \mathrm{~cm}$. In all the years rice crop was transplanted in second week of July and garlic crop was planted immediately after harvest of rice. The fertilizer dose in all the treatments were kept $120 \mathrm{~kg}$ nitrogen per hectare which was given $1 / 3$ through FYM, $1 / 3$ through vermicompost and $1 / 3$ through neem cake. In $\mathrm{T}_{6}$ treatment @50 quintal mustard oilcake per hectare was given in rice and garlic. The weed control treatments were $\mathrm{T}_{1}$-Hand weeding 20 and 40 DAT in rice and 40 and 80 DAP in garlic, $\mathrm{T}_{2}$-Conoweeder or hoeing at $20 \mathrm{DAT}+$ one $\mathrm{HW}$ at $40 \mathrm{DAT}$ in rice and 40 and $80 \mathrm{DAP}$ in garlic, $\mathrm{T}_{3}$-Inter cropping with Dhaincha in rice and mustard in garlic (3:1), $\mathrm{T}_{4}$-Stale seed bed + reduced spacing up to $25 \%+$ mulching with wheat straw + one hand weeding, $\mathrm{T}_{5}$-Locally available weed mulch +1 hand weeding, $\mathrm{T}_{6^{-}}$ Incorporation of mustard oil cake @ 50 q/ha + $1 \mathrm{HW}$ and $\mathrm{T}_{7}$-ITK treatment on mulching with mango tree dry leaf @ 3t/ha practiced by farmers under organic production system. These treatments were arranged in Randomised Block Design and replicated thrice. All recommended package of practices were adopted for irrigated condition.

\section{Results and Discussion}

\section{Effect on rice}

Data pertaining to grain yield of rice under different weed management practices under 
organic production system has been given in Table-1. After perusal of the pooled result for different years it is evident that grain yield of rice $(53.23 \mathrm{q} / \mathrm{h})$ was maximum in $\mathrm{T}_{1}$ where two hand weeding was given at $25 \& 50$ DAT followed by $\mathrm{T}_{6}$ in which mustard oilcake 50 quintal per hectare along with one hand weeding was given $(53.02 \mathrm{q} / \mathrm{ha})$. These treatments gave $39 \%$ to $40.16 \%$ higher grain yield of rice as compared to existing farmers practices of mulching with mango leaves in $\mathrm{T}_{7}$. Other weed control treatment in rice gave $10.73 \%$ to $27.29 \%$ higher grain yield of rice over farmers practices of mulching with mango leaves in $\mathrm{T}_{7}$.

Table.1 Economic yield of Rice-Garlic cropping system under different weed control practices in organic production system

\begin{tabular}{|c|c|c|c|c|c|c|c|c|}
\hline \multirow[t]{2}{*}{ Treatment } & \multicolumn{4}{|c|}{ Rice yield (q/ha) } & \multicolumn{4}{|c|}{ Garlic yield (q/ha) } \\
\hline & 2017-18 & 2018-19 & 2019-20 & Mean & 2017-18 & 2018-19 & 2019-20 & Mean \\
\hline $\begin{array}{l}T_{1} \text { Two hand } \\
\text { weeding } 25 \text { and } 50 \\
\text { DAT }\end{array}$ & 44.09 & 59.63 & 56.26 & $\begin{array}{c}\mathbf{5 3 . 3 2} \\
(40.61)\end{array}$ & 53.36 & 109.80 & 107.04 & $\begin{array}{c}90.06 \\
(72.52)\end{array}$ \\
\hline $\begin{array}{l}\mathrm{T}_{2} \text { Hoeing at } 25 \text { DAT } \\
+ \text { one } \mathrm{HW} \text { at } 50 \\
\text { DAT }\end{array}$ & 41.47 & 48.52 & 54.81 & $\begin{array}{c}\mathbf{4 8 . 2 7} \\
(27.29)\end{array}$ & 47.47 & 73.90 & 95.41 & $\begin{array}{c}72.26 \\
(38.42)\end{array}$ \\
\hline $\begin{array}{l}T_{3} \text { Inter cropping } \\
\text { with dzhaincha in } \\
\text { rice and mustard in } \\
\text { garlic in } 3: 1\end{array}$ & $\begin{array}{c}37.7 \mathrm{R} \\
156.4 \mathrm{G} \\
\mathrm{M}\end{array}$ & $\begin{array}{c}38.54 \mathrm{R} \\
112.5 \mathrm{G} \\
\mathrm{M}\end{array}$ & $\begin{array}{c}49.75 \mathrm{R} \\
133.10 \mathrm{G} \\
\mathrm{M}\end{array}$ & $\begin{array}{c}\text { 41.99R } \\
(10.73) \\
\text { 134G } \\
\text { M }\end{array}$ & $\begin{array}{l}20.24 \mathrm{G} \\
12.82 \mathrm{M}\end{array}$ & $\begin{array}{l}43.23 \mathrm{G} \\
15.20 \mathrm{M}\end{array}$ & $\begin{array}{l}36.57 \mathrm{G} \\
13.05 \mathrm{M}\end{array}$ & $\begin{array}{l}33.34 \mathrm{G} \\
(-36.13) \\
13.69 \mathrm{M}\end{array}$ \\
\hline $\begin{array}{l}\mathrm{T}_{4} \text { Stale seed bed + } \\
\text { reduced spacing up } \\
\text { to }(25 \%)+\text { mulching } \\
\text { with wheat straw + } \\
\text { one hand weeding }\end{array}$ & 42.38 & 44.43 & 55.68 & $\begin{array}{c}\mathbf{4 7 . 5 0} \\
(25.26)\end{array}$ & 41.37 & 56.37 & 69.60 & $\begin{array}{l}55.78 \\
(6.85)\end{array}$ \\
\hline $\begin{array}{l}T_{5} \text { Locally available } \\
\text { weed mulch }+1 \\
\text { hand pulling }\end{array}$ & 47.06 & 47.35 & 47.12 & $\begin{array}{c}\mathbf{4 7 . 1 8} \\
(24.41)\end{array}$ & 41.91 & 61.60 & 41.47 & $\begin{array}{c}48.32 \\
(-7.42)\end{array}$ \\
\hline $\begin{array}{l}\mathbf{T}_{6} \text { Incorporation of } \\
\text { mustard oil cake } 15 \\
\text { days before sowing } \\
\text { @ } 50 \mathrm{q} / \mathrm{ha}+\mathbf{1 H W}\end{array}$ & 54.78 & 53.78 & 50.51 & $\begin{array}{c}\mathbf{5 3 . 0 2} \\
(39.82)\end{array}$ & 79.24 & 143.76 & 112.67 & $\begin{array}{l}111.89 \\
(114.3)\end{array}$ \\
\hline $\begin{array}{l}T_{7} \text { ITK treatment on } \\
\text { weed control } \\
\text { practiced by } \\
\text { farmers as mulching } \\
\text { with leaf of mango }\end{array}$ & 35.84 & 34.20 & 43.73 & $\begin{array}{l}\mathbf{3 7 . 9 2} \\
(0.00)\end{array}$ & 43.58 & 59.30 & 53.65 & $\begin{array}{l}52.20 \\
(0.00)\end{array}$ \\
\hline SEM \pm & 3.02 & 2.15 & 1.75 & 2.30 & 3.10 & 3.42 & 2.35 & 2.9 \\
\hline CD at $5 \%$ & 9.28 & 6.60 & 5.18 & 7.02 & 8.81 & 10.52 & 6.95 & 8.76 \\
\hline
\end{tabular}

Figures in parentheses are $\%$ increase (+) or \% decrease (-) over $\mathrm{T}_{7}$ 
Table.2 Average rice equivalent yield, gross return, net return and B:C ratio under different weed control practices in organic production system (3 years pooled)

\begin{tabular}{|c|c|c|c|c|}
\hline Treatment & $\begin{array}{c}\text { Rice } \\
\text { equivalent } \\
\text { yield }\end{array}$ & $\begin{array}{c}\text { Gross } \\
\text { return Rs/ha }\end{array}$ & Net return $\mathrm{Rs} / \mathrm{ha}$ & B:C Ratio \\
\hline & Mean & Mean & Mean & Mean \\
\hline $\begin{array}{l}T_{1} \text { Two hand weeding } 25 \text { and } 50 \\
\text { DAT }\end{array}$ & $\begin{array}{l}198.83 \\
(56.19)\end{array}$ & $\begin{array}{l}423787 \\
(55.52)\end{array}$ & $\begin{array}{l}236900 \\
(98.19)\end{array}$ & $\begin{array}{c}2.24 \\
(28.73)\end{array}$ \\
\hline $\begin{array}{l}\mathrm{T}_{2} \text { Cono weeder } 25 \mathrm{DAT}+\text { one } \mathrm{HW} \text { at } \\
\text { 50DAP }\end{array}$ & $\begin{array}{l}166.93 \\
(31.13)\end{array}$ & $\begin{array}{l}268930 \\
(-1.30)\end{array}$ & $\begin{array}{l}187738 \\
(31.96)\end{array}$ & $\begin{array}{c}2.08 \\
(19.54)\end{array}$ \\
\hline $\begin{array}{l}T_{3} \text { Inter cropping with Dhaincha in } \\
\text { 3:1 }\end{array}$ & $\begin{array}{l}125.76 \\
(-1.20)\end{array}$ & $\begin{array}{c}268246 \\
(-1.55)\end{array}$ & $\begin{array}{l}127584 \\
(06.73)\end{array}$ & $\begin{array}{c}1.90 \\
(9.19)\end{array}$ \\
\hline $\begin{array}{l}T_{4} \text { Stale seed bed + reduced spacing } \\
\text { up to }(25 \%)+\text { mulching with wheat } \\
\text { straw + one hand weeding }\end{array}$ & $\begin{array}{l}142.74 \\
(12.12)\end{array}$ & $\begin{array}{l}305988 \\
(11.55)\end{array}$ & $\begin{array}{l}132104 \\
(10.51)\end{array}$ & $\begin{array}{c}1.75 \\
(0.57)\end{array}$ \\
\hline $\begin{array}{l}T_{5} \text { Locally available weed mulch }+1 \\
\text { hand pulling }\end{array}$ & $\begin{array}{l}127.29 \\
(-0.01)\end{array}$ & $\begin{array}{c}271328 \\
(-1.08)\end{array}$ & $\begin{array}{l}108356 \\
(-9.34)\end{array}$ & $\begin{array}{c}2.67 \\
(-4.02)\end{array}$ \\
\hline $\begin{array}{l}T_{6} \text { Incorporation of mustard oil cake } \\
15 \text { days before sowing @ } 50 \mathrm{q} / \mathrm{ha} \\
+1 \mathrm{HW}\end{array}$ & $\begin{array}{l}237.69 \\
(86.74)\end{array}$ & $\begin{array}{l}506902 \\
(84.80)\end{array}$ & $\begin{array}{l}172516 \\
(44.32)\end{array}$ & $\begin{array}{c}1.50 \\
(-13.7)\end{array}$ \\
\hline $\begin{array}{l}T_{7} \text { ITK treatment on weed control } \\
\text { practiced by farmers as mulching } \\
\text { with leaf of mango }\end{array}$ & $\begin{array}{l}127.30 \\
(0.00)\end{array}$ & $\begin{array}{c}272492 \\
(0.00)\end{array}$ & $\begin{array}{c}119530 \\
(0.00)\end{array}$ & $\begin{array}{c}1.74 \\
(0.00)\end{array}$ \\
\hline S.Em \pm & 1.81 & - & - & - \\
\hline CD at $5 \%$ & 5.26 & - & - & - \\
\hline
\end{tabular}

Figures in parentheses are \% increase or decrease over $\mathrm{T}$

Table.3 Weed dry weight $\mathrm{g} / \mathrm{m}^{2}$ and Weed control efficiency at harvest in rice-garlic under different weed control practices in organic production system (3 years pooled)

\begin{tabular}{|c|c|c|c|c|}
\hline \multirow[t]{2}{*}{ Treatment } & \multicolumn{2}{|c|}{$\begin{array}{l}\text { Weed dry weight } \\
\mathrm{g} / \mathrm{m}^{2}\end{array}$} & \multicolumn{2}{|c|}{$\begin{array}{l}\text { Weed control } \\
\text { efficiency \% }\end{array}$} \\
\hline & Rice & Garlic & Rice & Garlic \\
\hline T 1 Two hand weeding 25 and 50 DAP & 49.54 & 65.36 & 54.13 & 62.04 \\
\hline $\mathrm{T}_{2}$ Hoeing at $25 \mathrm{DAP}+$ one $\mathrm{HW}$ at $50 \mathrm{DAP}$ & 61.75 & 90.55 & 42.06 & 44.12 \\
\hline $\begin{array}{l}T_{3} \text { Inter cropping with dhaincha in rice and mustard } \\
\text { in garlic in 3:1 }\end{array}$ & 86.51 & 128.94 & 37.89 & 34.99 \\
\hline $\begin{array}{l}T_{4} \text { Stale seed bed + reduced spacing up to }(25 \%)+ \\
\text { mulching with wheat straw + one hand weeding }\end{array}$ & 56.34 & 165.44 & 39.93 & 21.24 \\
\hline$T_{5}$ Locally available weed mulch +1 hand pulling & 64.01 & 195.55 & 34.93 & 11.32 \\
\hline $\begin{array}{l}\mathrm{T}_{6} \text { Incorporation of mustard oil cake } 15 \\
\text { days before sowing @ 50q/ha }+1 \mathrm{HW}\end{array}$ & 34.46 & 103.50 & 66.24 & 58.47 \\
\hline $\begin{array}{l}T_{7} \text { ITK treatment on weed control practiced by } \\
\text { farmers as mulching with leaf of mango }\end{array}$ & 105.5 & 207.44 & - & - \\
\hline SEM \pm & - & - & - & - \\
\hline CD at $5 \%$ & - & - & - & - \\
\hline
\end{tabular}


In treatment $\mathrm{T}_{3}$ where $25 \%$ rows of rice were replaced by dhaicha which incorporated the $13.4 \mathrm{t} /$ ha green manure increase the yield by $10.37 \%$ as compared to farmer practice of mulching with leaves in $\mathrm{T}_{7}$. It may be due to effective weed control which reduces the weed biomass over $T_{7}$ considerably which favours the rice crop to grow luxuriously with superior yield attributes. Incorporation of oilcake@ 50 q/ha along with one hand weeding gave $39.82 \%$ higher yield over farmers practice in $\mathrm{T}_{7}$. Beneficial effect of mustard oilcake@ $@ 50$ q/ha + one hand weeding supplied the extra nutrients by which crop grow luxuriously. Similar findings were also reported bye Islam et al (2007) Prajapat et al., (2019) and Aske et al., (2018).

\section{Effect on garlic}

Garlic bulb yield from 2017-18 to 2019-20 along with average value have been given in Table-1. It is clear from the data that garlic yield (111.89 q/ha) was significantly maximum where mustard oil cake was applied @ 50 quintal per hectare along with one hand weeding. This treatment gave $114.34 \%$ higher bulb yield over farmers practice of weed control in $\mathrm{T}_{7}$. The higher yield under incorporated of mustard oil cake @ $50 \mathrm{q} / \mathrm{ha}$ along with one hand weeding was due to supply of nutrients (in concentrate form) more than the quantity required for growth by which bulb size and number of cloves per bulb were increased considerably. Weed control efficiency $58.47 \%$ was also higher in $\mathrm{T}_{6}$ where incorporation of mustard oil cake @ 50 q/ha was done in garlic. Two hand weedings were given at 40 and 80 DAP in $\mathrm{T}_{1}$ gave the bulb yield $90.06 \mathrm{q} / \mathrm{ha}$ which was $72.52 \%$ higher than existing farmer practice of mulching as weed control $\left(\mathrm{T}_{7}\right)$. The bulb yield was reduced in $T_{3}$ (intercropping with mustard) but it also gave mustard yield $13.96 \mathrm{q} / \mathrm{ha}$. It may be due to a toxic effect of mustard which reduce the bulb yield of garlic. Similarly bulb yield of garlic was also reduced by $7.42 \%$ in $\mathrm{T}_{5}$ where locally weed mulch along with one hand weeding was given as weed control treatment.

\section{Effect on rice equivalent yield}

Rice equivalent yield of rice-garlic cropping system under different weed management practices has been presented in Table-2. It is clear from the result that rice equivalent yield $237.69 \mathrm{q} / \mathrm{ha}$ was maximum due to application of @ 50 quintal mustard oil cake per hectare along with one hand weeding given $\left(\mathrm{T}_{6}\right)$ followed by $198.83 \mathrm{q} / \mathrm{ha}$ under two hand weeding given in rice and garlic at different intervals. These treatments gave $56.19 \%$ to $86.74 \%$ higher grain yield of rice as compared to farmers practice. It is because of the fact that two hand weeding in $T_{1}$ effectively reduce the weed biomass as compared to farmers practice which also gave higher weed control efficiency i.e. 62 to $63 \%$ and also favours the rice and garlic crop to grow vigorously with superior yield attributes. Superiority of two hand weeding in rice and garlic was also reported by Ramamoorthy et al., (2009), Prajapati et al., (2019) and Aske et al., (2018). Rice equivalent yieldof rice-garlic cropping system was $86.71 \%$ higher under incorporation of mustard oil cake applied @ 50 q/ha along with one hand weeding over farmers practice of mulching $\left(\mathrm{T}_{7}\right)$. Intercropping of dhaicha in rice and mustard in garlic exerted teletoxic effect in intercropping by which rice equivalent yield was reduced by $2 \%$ as compared to farmers practice of mulching $\left(\mathrm{T}_{7}\right)$. It may be due to excess supply of nutrient in concentrated form through mustard oil cake which favours the growth of rice and garlic over farmers practice. Beneficial effect of mustard oil cake on growth and yield of rice and garlic was also reported by Islam et al., (2007), Prajapat et al., (2019) and Anonymous (2020). 
Effect on gross, net profit and benefit cost ratio

The gross return and net return per hectare of rice-garlic under organic production system have been presented in Table-2. It is evident from the table that gross return 5,06,902 Rs/ha was maximum under incorporation of mustard oilcake @ 50 q/ha with one hand weeding which was $84.80 \%$ higher than farmers practice of mulching $\left(\mathrm{T}_{7}\right)$ followed by $4,23,787 \mathrm{Rs} / \mathrm{ha}$ under two hand weeding given in rice and garlic at different stages of growth which also gave $55.52 \%$ higher gross return than farmers practice. It may be due to lesser weed competition and higher nutrient availability. These treatments resulted to superior growth and yield of rice-garlic which gave higher return. Similar result was also reported by Anonymous (2020).

Net profit under different weed control management practices in rice-garlic under organic production system is given in Table- 2 reveals that net profit Rs/- 2,36,900 per hectare was maximum under two hand weeding followed by Rs/- 1,72,516 per hectare in incorporation of mustard oil cake @ $50 \mathrm{q} / \mathrm{ha}$ with one hand weeding given in rice\& garlic.

These treatment gave $44.32 \%$ to $98.19 \%$ higher net return over farmers practice of mulching $\left(\mathrm{T}_{7}\right)$ and lower net profit $\left(\mathrm{T}_{6}\right)$ in which mustard oil cake was given @ 50 quintal per hectare along with one hand weeding in rice and garlic was due to higher cost of oil cake which gave lower net profit.

The benefit cost ratio 2.24 was maximum under two hand weeding given in rice and garlic as weed control treatment followed by 2.08 under one hoeing plus one hand weeding given in $\left(\mathrm{T}_{2}\right)$. All other treatments gave benefit cost ratio less than 2 .

\section{Effect on weeds}

The major dominating weeds in rice crop were Jussia subffrustica, Monochoria vaginalis, Echinocloa colonum and Frimbristylis dicotoma. The garlic crop was infested with Medicago hyspida, Heliotropium indicum, Vicia sativa, Anagallis arvensis and Phalaris minor.

\section{Weed dry matter and weed control efficiency}

Dry weight and weed control efficiency of different weed control practices under organic production system have been given in Table3 . It is clear from the result that weed dry weight 105.5 gram per square meter was maximum in farmers practice of mulching $\left(\mathrm{T}_{7}\right)$ while weed dry weight 34.46 gram per square metre was lowest under incorporation of mustard oil cake @ 50 quintal per hectare plus one hand weeding preceded by 49.59 gram per square metre under two hand weeding in rice. The weed dry matter in garlic crop was minimum 65.36 gram per square metre under two hand weeding while it was maximum 207.4 gram per square metre in garlic under farmers practice of mulching $\left(\mathrm{T}_{7}\right)$. Weed control efficiency was maximum under two hand weeding i.e. $63 \%$ in rice and $62 \%$ in garlic followed by incorporation of mustard oil cake @ 50 quintal per hectare in rice and garlic which gave weed control efficiency $66.24 \%$ in rice and $58.47 \%$ in garlic. Similar findings were also reported by Prajapat et al., (2019) and Aske et al., (2018).

\section{References}

Anonymous. 2017. Kharif outlook 2017-18 in rice. www.skymetweather.com.

Anonymous. 2020. Annual progress report All India Coordinated Research Project on Integrated Farming System, Rewa Madhya Pradesh. 
Aske Sachin, BM Maurya, Jugnahake Monika and S.M. Kurmvanshi. 2018. weed management in organically grown scented rice. Indian Journal of Weed Science 50(4): 391-394.

Bhan VM, Singh M and Maurya RA. 1970. Weed control in field crops. Pans. 16(4): 684-701.

Bhan VM. 1968. Influence of row spacing on upland paddy. IL Riso.17: 149-154.

Bond W and Grundy AC. 2001. Nonchemical weed management in organic farming systems. Weed Research 41(5): 383-405.

Islam MM, Anwar MP, Rahman MM and Islam AKMM. 2007. Influence of mustard oil cake on the performance of fine rice $\mathrm{CV}$. Chinigara. International Journal of Bio Research. 3(6): 50-54.

Mukherjee PK, Anindya Sarkar and Maity SK. 2008. Critical period of crop-weed competition in transplanting and wetseeded kharif rice (Oryza sativa L.) under tarai conditions. Indian Journal of Weed Science 40 (3\&4): 147-152.

Prajapat Rohit, Mishra Priyanka, BM Maurya and S.M. Kurmavanshi. 2019. Thermal Response of Scented Rice under different weed management practices in organic production system. Int. J. Curr. Microbiol. App. Sci (2019) 8(3): 1833-1841. http://www.ijcmas.com.

Ramamoorthy K, Radhamani S and Subbaain P. 2009. Integrated weed management for the control of Trianthema portulacastrum $L$. in rainfed finger millet (Eleusine coracana L.Gaertn). Green Farming 2(4): 221-223.

Rao AN and Shetty SVR. 1981. Investigation on weed suppressing ability of smother cropping systems in relation to canopy development and light interception. pp 357-364. In: Proceedings of $8^{\text {th }}$ Asian Pacified Science Society Conference, Banglore, India

\section{How to cite this article:}

Singraul, A., B. M. Maurya, S. M. Kurmvanshi and Pradhan, Y. K. 2020. Weed Management in Rice-Garlic under Organic Production System. Int.J.Curr.Microbiol.App.Sci. 9(11): 1443-1449. doi: https://doi.org/10.20546/ijcmas.2020.911.170 